\title{
The Symbolic Power of Place Names: The Case of the River Olše/Olza/tolza in Northeastern Czechia
}

\author{
P̌̌EMYSL MÁcha \\ Institute of Ethnology, Czech Academy of Sciences, Brno, Czechia
}

It is not uncommon for place names to become symbols of national identity. Once in that position, such names often play a significant symbolic role in national and local politics. It is less common, however, for actual place name usage to significantly contradict declared place name preferences such that for official purposes people prefer a name variant that they do not use themselves. This article describes an instance of just such cognitive dissonance in a trilingual region in the Czech-Polish borderlands. As will be shown, arguments over which variant to use in this region have been marked by ongoing debates about multilingualism in the linguistic landscape. The parallel usage of the names Olše/Olza/tolza for the local river shows how important place names can be in articulating national belonging in spite of actual place name usage. The analysis is based on the results of a survey conducted on a large population sample. The questionnaire results are supplemented by interviews and secondary literature.

KEYWORDS place names, hydronyms, politics, identity, multilingualism, Czech, Polish

\section{Introduction}

In the following text, we present the results of a study undertaken between 2016 and 2018 in the Těšín region in northeastern Czechia. In the context of the country, this region is unique for its official bilingualism, de facto trilingualism, and a strong cultural and political presence of the Polish minority. Our research focused on observed differences in name preference and usage in relation to the local river called Olše, Olza or Lolza. ${ }^{\mathrm{I}}$ While the official name is Oľse, few people (regardless of their ethnicity) actually use it, preferring Olza and Lolza 
instead. However, all attempts at renaming the river to Olza have failed due to strong resistance from the local people. In our research, we investigated the reasons for this resistance and the role played by the river names in regional and national identity politics. Our principal research question was whether the symbolic power of names is necessarily dependent on their use in everyday life. The analysis is primarily based on a questionnaire of a representative population sample. This survey was supplemented by one-on-one interviews and archival and secondary sources.

\section{Theoretical Background}

As anthropologists and geographers, we are interested in place names because of their capacity to function as expressions, elements, and means of space-related identity building. Place names influence how we see and perceive the landscape around us and the people who occupy it. They shape landscape visibly through signposts and maps; and they help to define and express identity in space through the placement of bilingual signs in multiethnic regions (Jordan 2009). They have become a mainstay of anthropological and geographic research following the influential works of Basso (I988, I996) and Tuan (I99I) who both stressed the importance of place names for establishing and facilitating the intimate relationship between people and the space they occupy.

However, place names are rarely politically neutral but are often embedded in claims over territory, ethnic struggles, and assertions of power over space. The relationship between toponymy and power is complex and has been examined by what has come to be known as the 'critical toponymies approach' (Berg and Vuolteenaho 2009; Rose-Redwood, Alderman, and Azaryahu 2010). In this approach, place naming is seen as a social and political practice and a form of place making. It is an ongoing and contested social process that can be understood as a set of performative actions (Rose-Redwood 2008). The transcription and pronunciation of names is an integral part of their social function and emotional appeal (Kearns and Berg 2002).

In multilingual and multiethnic areas, questions of place names, identity, and political representation may become particularly entangled and they may even generate multiple conflicts. Place names in minority languages make the minority visible and may contribute to the vitality of the minority language (Cenoz \& Gorter 2006). At the same time, however, minority names may be perceived as a threat by the majority society or other minorities (Puzey 2009). As we demonstrate below, this is also true for names which are seen as minority names regardless of their true etymology, linguistic origin or everyday use.

The principal goal of our research was to understand the symbolic power of place names in multilingual settings. Specifically, we were interested in the extent to which names could be separated from their usage without losing their symbolic power. A number of studies have shown the importance of place names in the formation and expression of national identities (see e.g., Bucher 
et al. 20I3; Šakaja and Stanić 20II; Palonen 2008; Gill 2005; Light 2004; Alderman 2000; González-Faraco and Murphy I997; Azaryahu I996; Yeoh I996; Cohen and Kliot I992). Few of those studies have, however, confronted declared political preferences with actual everyday place naming practices, implicitly presuming a strong, if not perfect, correspondence between preference and usage. In our research, we combined geographic and anthropological approaches to place names in order to achieve a more complex understanding of the politics and poetics of toponymic practice as it is lived in multilingual and multiethnic societies at the intersection of language, identity, place, politics, and cultural heritage. By confronting official toponymy with political preferences and everyday practices we found not only that there need not be a necessary correspondence between these areas. We also discovered just how highly politically and emotionally charged names can be regardless of their actual use.

\section{Olše/Olza/ olza and the Regional Context}

Our research took place in the Těšín region in north-eastern Czechia. It is a trilingual region where Czech, Polish, and a local transitional dialect called po našimu ('in our language') are spoken. The majority of local inhabitants speak this dialect regardless of their nationality, although as our questionnaire showed dialect use was greater among members of the Polish minority. The dialect is mostly only spoken and rarely appears in text, although one can occasionally see it on signs. Polish is seldom spoken at home in Polish households where the dialect or Czech is preferred. However, Polish, as a defining feature of Polish nationality, is promoted as the official language of communication for the Polish minority. It is also the official language of instruction in Polish elementary schools and high schools. It is worth pointing out that because of this complex linguistic situation most names exist in three versions (Czech, Polish, and the transitional dialect) which may differ in stress, phonetics, pronunciation, declination, and transcription. It is rather interesting that the conflict over bilingual signs that has taken place in the region over the last decade has involved names in languages that few people actually use in everyday life.

In addition to its interesting linguistic situation, this region is also unique because it is the only one in the country in which a national minority (Polish in this case) has the right to use a minority language in official communication, schooling, and on public signs. The legal threshold for exercising this right is a I०\% share of the local population, as measured by the last two population censuses. In many villages, the actual share reaches $30 \%$. Overall, however, the Polish population is in decline. Paradoxically, while the Polish representatives fear statistical extinction, many Czechs worry their land is being taken away from them by the Poles through bilingual signage. 


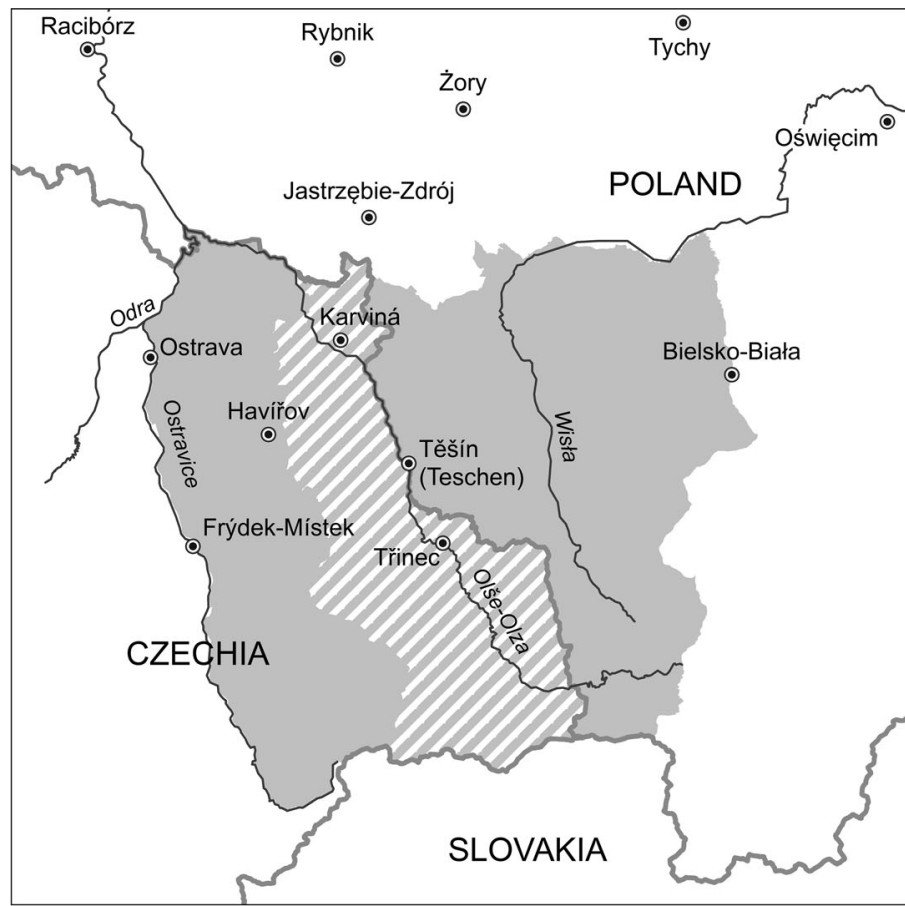

\section{Location of the Těšín region}

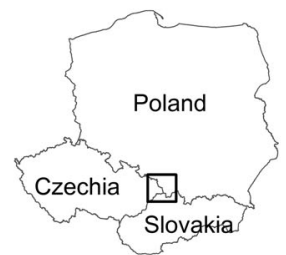

Legend
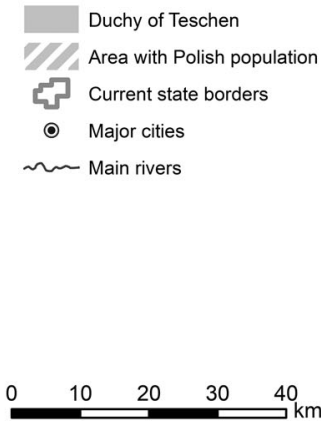

Map 1. Location of the Těšín region and the Polish minority area in Czechia.

Especially since the ratification and implementation of the European Charter for Regional or Minority Languages in 2007, the region has witnessed increased tensions over the appearance of bilingual Czech-Polish signs. These signs have transformed the linguistic landscape and seriously affect CzechPolish relations, both official and unofficial. Through the implementation of bilingual signage, the Polish minority suddenly became visible in the linguistic landscape. This development was perceived as a threat to homeland claims by some members of the Czech majority. As a consequence, Polish signs are frequently vandalized. However, Czech-Polish relations have long been highly sensitive issue due to historical grievances associated with the conflict over the control of the Těšín region by Czechoslovakia and Poland in the first half of the twentieth century. This conflict (including a brief war) led to the division of the historic region into Czechoslovak and Polish areas in 1920. The Czechoslovak part faced repeated attempts at annexation by Poland, including one in 1938 that temporarily succeeded. The memory of the resulting expulsions and repressions that accompanied this conflict are still alive in many local families. For some of these families, the appearance of Polish signs can trigger these past fears.

It is in this context that we carried out our research. The results of our investigation must be interpreted with this historical background in mind. For our study, we focused on the name of the local river Olše/Olza/Lolza which runs 
through the entire region, both connecting as well as dividing it. It begins in the Polish part of the Těšín region. It then flows through the interior of Czechia to become a border river before ending in a confluence with the river Odra. The historic (and dialectal) name of the river is Olza (or also Łolza). It appears in the earliest documents variously transcribed as Olza, Olsa or Oelsa. In its etymology, it is related to other old Slavic names such as Volga, meaning 'river with plentiful water' (Lutterer and Šrámek 2004).

This original meaning, however, is not transparent to most speakers of Czech or Polish. As a result, in early I900s, both Polish and Czech nationalists attempted to rename the river, albeit for different reasons. For many Poles, the original river name sounded too German and reminded them of a time of the Austro-Hungarian Empire when the German minority in the Těšín region was very influential. The name Olsza was created to refer to the alder trees found along its banks (i.e., olcha or olsza). This name, however, never caught on, and Olza remained the official name of the river in Poland. Czechoslovakia officially renamed the river to Olše in I9I8, also choosing the alder tree as a transparent motivation (i.e., olše). However, the reasons for renaming were different than in the Polish case. To the Czech nationalists, Olza did not sound German but Polish, and it is this "Polish" connotation that is preserved up to this day in the minds of many local inhabitants (Gawrecki I993). The renaming process lasted many decades, and gradually impacting all the name derivatives (e.g., names of settlements on the river, names of train stations, etc.). Some changes occurred even as late as I950s when, for example, Bystrice nad Olzou changed to Bystřice nad Olš́.

It is important to note that the difference between the names Olše, Olza and Łolza is not simply orthographic but also phonetic. Their pronunciation is distinct and the names cannot be mistaken. As we have found, for a great number of speakers, the auditory quality of the name is an integral component of the speakers' onymic preference. Furthermore, the choice of the name variant clearly reflects the speaker's identity, be it regional or national. The usage of Olza/Lolza signals regional ties in most everyday conversations. However, in specific contexts, such as a meeting between the representatives of the Polish minority and Czech government officials, it may be interpreted as a sign of Polish identity instead. The usage of Olše in everyday conversations, by contrast, may either express a political position in the conflict over the Těśín region; or it may simply betray that a speaker comes from outside of the local area and has not yet learned the dialect.

Over the last three decades, there have been repeated attempts by the Czech Place Name Commission to either change the name of the Czech section of the river back to Olza or to recognize the original name as an equal alternative to Olše. However, all these attempts have failed due to a fierce resistance from certain institutions, interest groups, and many local inhabitants who considered the name Olza to be Polish and feared that its official use would weaken the Czech claim to the territory. It is, nevertheless, a well-known fact that the 
majority of local inhabitants, irrespective of their nationality, use Olza (or Łolza) in everyday life. We were therefore faced with an intriguing research question. Our study also had direct application to the work of the Place Name Commission who asked us to investigate the popular usage of Olza and measure potential support for its official recognition. This article presents what we found.

\section{Methods}

Between January and March 2018, we carried out a questionnaire in towns and villages in the Těšín region. We distributed 3500 questionnaires mostly through schools and companies and received I 807 usable questionnaires back from 47 settlements. We believe the return rate was so high because of the political salience of the questionnaire. We used quota sampling based on age, gender, education, residence, and nationality. The resulting sample structure followed rather closely the structure of the general population, although university educated, young people, and Poles were slightly overrepresented. Of the respondents $70 \%$ were Czech; 25\% were Polish; and the remaining 5\% identified as Slovak, Silesian, or other. For the purpose of the following analysis, we only selected respondents who identified as Czech or Polish ( $n=\operatorname{I7}$ I 8). In the questionnaire, we focused on language use; attitudes towards bilingual signs; and the preference for and usage of the river name. To maintain maximum neutrality, the questionnaire was available in both Czech and Polish. The questionnaire contained nineteen questions. Most of them were multiple choice or Likert scale ratings, and four were partly open-ended questions. In this text, we report the results of only four of these questions which are directly relevant to the topic at hand.

Before starting the survey, we had carried out over Io5 $_{5}$ in-depth semi-structured interviews with local inhabitants and political representatives. This step was taken in order to gain good insight into how people think about language, names, signs, and identity. Thanks to these interviews, we were able to identify key issues and formulate appropriate questions for the survey. Thanks to the representativeness of the survey sample, the statistical results obtained have potentially high social significance. The survey made it possible to test different hypotheses which were either inspired by previous research or which emerged during our preliminary interviews. We ran our statistical tests using the IBM SPSS Statistics software and these results are included under each table.

One of the interviews that most motivated us to include specific questions on Olza in our survey was an interview with a Czech woman, age 55, from the village of Bystrice nad Olší. This respondent normally uses the dialectal form Łolza as the name for the river flowing through her village. The information this interviewee provided illustrates very well the intuitive and practical ability 
of local people to differentiate between the relevance of different names for identity delineation in everyday conversations:

Researcher: "Is it important for you how a name is written or pronounced?"

Respondent: "Yes, Bystrica nad Łolzum, or nad Olší, I would prefer the Czech name. I don't know how it is correctly, based on history, but I would prefer nad Olší."

Researcher: "Why would you prefer the Czech form?"

Respondent: "Well, we live in the Czech Republic, so it is the Czech name."

Researcher: "And what about other names such as Guchufka (dialect) vs Hluchová (Czech)?”

Respondent: "Guchufka is po našimu ('in our language'), it is a completely different thing!"

This interview underlined the key questions we set out to explore: how many people actually use Olza?; how do they perceive the name and how does the perceived national origin of a name influences its use and preference?; how many people would like to see Olza as the official name of the river and why or why not?; and how do we explain the observed differences in opinion? We used these research questions in our survey. These items are provided in translation in Figure I.

\begin{tabular}{lll}
\hline Table 1 & $\begin{array}{l}\text { Q1 - Which variant of the river } \\
\text { name Olza/Olše do you use in } \\
\text { everyday life? }\end{array}$ & $\begin{array}{l}\text { a) I use exclusively Olza } \\
\text { b) I use predominantly Olza } \\
\text { c) I use equally often Olza and Olše } \\
\text { d) I use predominantly Olše } \\
\text { e) I use exclusively Olše }\end{array}$ \\
Table 2 and 5 & $\begin{array}{l}\text { Q2 - Do you see the name Olza } \\
\text { as..........? }\end{array}$ & $\begin{array}{l}\text { a) a Czech name } \\
\text { b) a Polish name } \\
\text { c) a dialectal name } \\
\text { d) other (explain): }\end{array}$ \\
Tables 3-5 & $\begin{array}{ll}\text { Q3 - Should the name Olza } \\
\text { become the official name of the } \\
\text { river? Please, explain why or why } \\
\text { not. }\end{array}$ & $\begin{array}{l}\text { a) yes } \\
\text { b) I do not know }\end{array}$ \\
& $\begin{array}{l}\text { Qxplanation: } \\
\text { All tables }\end{array}$ & $\begin{array}{l}\text { a) Czech } \\
\text { b) Polish } \\
\text { c) Slovak } \\
\text { d) Silesian } \\
\text { e) other (specify): }\end{array}$ \\
\end{tabular}

FIGURE 1. Survey Questions Analyzed in this Text. 
As mentioned earlier, the entire scope of our research was much wider than what we have space to present here. We also analyzed archival sources to understand nationalistically motivated place name changes in the region (see e.g., Mácha, Lassak, and Krtička 20I9). In addition, we analyzed the media coverage of place names conflicts. We documented the linguistic landscape and analyzed it both qualitatively and quantitatively. We also analyzed the perceptions, attitudes, and ideas of local people in relation to names, identity, language, and signs (all to be published in an upcoming book). The findings presented in this article therefore are only a small fraction of a larger investigatory mosaic, but one that is very important for in the analysis of a single name all of the aspects we were interested in are brought together. It would be rather presumptuous to generalize our findings to the world. However, we are fairly confident that in the context of Central Europe, our results have a special relevance and may point to interesting problems to be taken up by future researchers elsewhere.

\section{Findings}

The first question related to Olše/Olza in our survey concerned its actual usage. The respondents were presented with five choices, ranging from exclusive use of Olza or Olše to equal use of both. As Table I shows, $67.6 \%$ of respondents use Olza exclusively or predominantly and only г2.I\% of people use exclusively or predominantly Olše. When we break down those numbers by nationality (people self-identified as Czech or Poles, excluding the small number of people who self-identified as having other nationalities), we get a similar picture although there is a significantly higher preference for Olza among Poles. Even then, however, only $\mathrm{I} 7 \%$ of Czechs use exclusively or predominantly Olše. From these numbers it is clear that the preferred name is Olza, regardless of the respondents' nationality. This finding confirms what the respondents presumed was the case during our interviews and also matches what we observed.

Table 1. Respondents' use of Olza/Olše by Percentage as Reported in Survey Q1 and Q4

\begin{tabular}{lccccrr}
\hline & \multicolumn{5}{c}{ Which variant of the river name Olza/Olše do you use in everyday life? } \\
\cline { 2 - 6 } & Only Olza & Mostly Olza & Both equally & Mostly Olše & Only Olše & Total \\
\hline Czechs & 31.7 & 30.8 & 20.5 & 7.8 & 9.2 & 73.3 \\
Poles & 77.3 & 17.4 & 4.1 & 0.7 & 0.4 & 26.7 \\
All respondents & 41.7 & 25.9 & 15.3 & 5.6 & 6.5 & 100.0 \\
\end{tabular}

Note: $\mathrm{n}=1718$, Pearson $\chi^{2}$ value $=304,467, \mathrm{df}=4, \mathrm{p}=.000$

The next question asked whether the respondents viewed the name Olza as Czech, Polish, dialectal, or other. Table 2 summarizes the results. Overall, $42.7 \%$ saw the name as dialectal and $36.7 \%$ as Polish. However, if we break 
down the numbers by nationality, we see again a clear, statistically significant correlation between nationality and name perception. While $50.8 \%$ of Czechs considered the name to be dialectal and only $26.5 \%$ to be Polish, the numbers were reversed for Poles. $64.7 \%$ saw it as Polish and only $20.5 \%$ as dialectal. It is noteworthy that in the context of the following reservations, only $17.7 \%$ of Czechs saw the name as Czech. As for the last option, it was mostly chosen by people who knew the real etymology of the name and they usually added an explanation supporting their usage.

Table 2. Respondents' Perception of Olza as a Czech/polish/dialectal Name by Percentage as Reported In Survey Q2 and Q4

\begin{tabular}{lccccr}
\hline & \multicolumn{5}{c}{ Do you see the name Olza as .........? } \\
\cline { 2 - 6 } & Czech & Polish & Dialectal & Other & Total \\
\hline Czechs & 17.7 & 26.5 & 50.8 & 4.9 & 73.3 \\
Poles & 3.1 & 64.7 & 20.5 & 11.8 & 26.7 \\
All respondents & 13.8 & 36.7 & 42.7 & 6.8 & 100.0 \\
\hline
\end{tabular}

Note: $\mathrm{n}=1718$, Pearson $\chi^{2}$ value $=281,749, \mathrm{df}=3, \mathrm{p}=.000$.

After gathering information about the respondents' name use and ethnic perception, we asked whether Olza should become the official name of the river. The answers were rather surprising and contrasted sharply with responses to the first question. We expected to find a general correlation between name use and preference but the situation was significantly more complex. Table 3 summarizes the details. Overall, the sample was divided roughly into thirds: one-third supported the name change; one-third opposed it; and one-third did not feel competent to respond. However, a significantly different picture emerged when we compared the Czechs and Poles. While only i9.I\% of Czechs were supportive of the change, $68 \%$ of Poles held the same opinion. From within the context of the first question, while nearly two-thirds of Czechs used exclusively or predominantly Olza, less than one-fifth of them wanted it to become the official name of the river. Also, while $94.7 \%$ of Poles used exclusively or predominantly the name Olza, only $68 \%$ of them wanted it to become the official name. Something very interesting seemed to be emerging in the data.

Table 3. Respondents' Support for Olza as the Official Name by Percentage as Reported In Survey Q3 and Q4

\begin{tabular}{lcccc}
\hline & \multicolumn{4}{c}{ Should the name Olza become the official name of the river? } \\
\cline { 2 - 5 } & Yes & No & Doesn't know & Total \\
\hline Czechs & 19.1 & 45.7 & 35.2 & 73.3 \\
Poles & 68.0 & 10.2 & 21.8 & 26.7 \\
All respondents & 32.2 & 36.2 & 31.6 & 100.0 \\
\hline
\end{tabular}

Note: $\mathrm{n}=1718$, Pearson $\chi^{2}$ value $=384,927, \mathrm{df}=2, \mathrm{p}=.000$. 
As part of the previous question, we asked respondents to explain their position on the official status of Olza. It was an open-ended question and they could respond as they wished. Slightly over a third of all respondents provided an answer. Although most chose a brief explanation, some wrote a whole paragraph which was often very emotional. Because these responses were not standardized, we grouped them into several distinct categories based on their prevailing content, and analyzed them statistically. The coding was done by the author. Table 4 shows the results. The relationships presented in this table could not be tested in a single test, but we had to run three independent tests. The first was on differences in argument use between Czechs and Poles (Pearson $\chi^{2}$ value $=\mathrm{I99,954}, \mathrm{df}=5, \mathrm{p}=.000)$, the second was on differences in argument use between Czechs who support and oppose Olza (Pearson $\chi^{2}$ value $=280,672, \mathrm{df}$ $=5, \mathrm{p}=.000)$, and the third was on differences in argument use between Poles who support and oppose Olza (Pearson $\chi^{2}$ value $=80,800, \mathrm{df}=5, \mathrm{p}=.000$ ) Figure 2 gives examples of typical responses in each category.

Table 4. Respondents' Arguments For/against Olza As The Official Name By Percentage As Reported In Survey Q3 And Q4

\begin{tabular}{lcccccrr}
\hline & \multicolumn{7}{c}{ Argument type } \\
\cline { 2 - 7 } & Utilitarian & Ideological & Aesthetic & Historic & Pragmatic & Other & Total \\
\hline Czechs for & 51.6 & 3.9 & 14.8 & 23.2 & 3.9 & 2.6 & 24.7 \\
Czechs against & 2.1 & 74.0 & 2.9 & 1.7 & 9.9 & 9.5 & 38.5 \\
Poles for & 8.9 & 7.0 & 8.5 & 66.2 & 3.8 & 5.6 & 33.9 \\
Poles against & 0.0 & 77.8 & 5.6 & 0.0 & 5.6 & 11.1 & 2.9 \\
All respondents & 16.6 & 34.1 & 8.2 & 28.8 & 6.2 & 6.5 & 100.0 \\
\hline
\end{tabular}

Note: $\mathrm{n}=628$.

\begin{tabular}{|c|c|c|}
\hline $\begin{array}{l}\text { Argument } \\
\text { category }\end{array}$ & Explanation & Example \\
\hline Utilitarian & $\begin{array}{l}\text { Based on prevalent number of } \\
\text { users }\end{array}$ & Most people use this name. \\
\hline Ideological & Based on nationalist preference & $\begin{array}{l}\text { In Czechia only Czech names } \\
\text { should be used. }\end{array}$ \\
\hline Aesthetic & $\begin{array}{l}\text { Based on subjective aesthetic } \\
\text { quality of the name }\end{array}$ & It sounds better. \\
\hline Historical & $\begin{array}{l}\text { Based on claims of (objective) } \\
\text { antiquity }\end{array}$ & It is the original name. \\
\hline Pragmatic & $\begin{array}{l}\text { Based on practical considerations } \\
\text { of impacts }\end{array}$ & It would cost a lot of money. \\
\hline Other & None of the above & $\begin{array}{l}\text { It does not matter what the river is } \\
\text { called. }\end{array}$ \\
\hline
\end{tabular}

FIGURE 2. Argument Categories with Explanations and Examples. 
As might already be expected, the general results hide significant differences between Czechs and Poles. There were also different attitudes towards the official name change which the respondents expressed. Taken all together then, there were four categories of respondents: Czechs for/against and Poles for/ against. As Table 4 clearly shows, both nationality and position on the name change influenced significantly the selection of arguments. While Czechs supporting the name change argued mostly in a utilitarian manner, Poles supporting the change preferred historical arguments. By contrast, Czechs opposed to the change mostly used ideological arguments which were also adopted by the small minority of Poles who were against the change.

The most frequently used ideological arguments typically included statements like "Olza is a Polish name" or "We are in the Czech Republic and we should use Czech names only". Such positions seem to have been frequently motivated by fears that the recognition of Olza would legitimize the Polish claim to the territory. One respondent (male, 45, from Mosty u Jablunkova) explicitly stated these fears: "The name is promoted by Polish nationalists to create tensions and strain the nerves of Czechs, they are compiling arguments for the future redrawing of state boundaries just as they did in I938." Interestingly, Poles against the name change used the same arguments, preferring to avoid direct confrontation with Czechs over an issue which was not very important to them (unlike, for example, schooling in Polish). This appeasing attitude may explain why only $68 \%$ of Poles supported the name change.

Czechs supporting the name change used mostly utilitarian arguments such as "Most people use Olza" or "Everyone says Olza." There were also many more radical statements such as "I have never heard anyone say Olše" or even "I did not know that Olza and Olše were the same river”. This utilitarian approach sharply contrasts with the ideological arguments against the name change. Interestingly, one respondent (male, Czech, 5 I, from Český Těšín) tried to use a utilitarian argument against the name change by reframing the relevant speech community: "The name Olza is used only by a small number of local people, the majority of the inhabitants of the Czech Republic use Olše."

Poles supporting the name change used mostly historical arguments such as "Olza is the original name of the river" or "It has always been called Olza." While on surface these arguments appear neutral, it is no coincidence that they were preferred so much by the Poles who like to emphasize their historical roots in the region. In some cases, these historical arguments tended towards Polish nationalism, for example, when allusion to the "anthem" of local Poles Ptyniesz Olzo po dolinie were made.

Somewhat aside stand the aesthetic arguments. These were present on both sides of the debate, although they were significantly more common in the camp supporting the name change (both Czech and Polish). Arguments such as "Olza sounds better" or "Olše is difficult to pronounce" or "Names should not be corrupted" were used to defend the name change. However, similar arguments 
were also used to argue the opposite: "It [i.e., Olza] does not sound like a name that should appear on maps" or "I like Olše more."

Furthermore, there were pragmatic and other, unclassifiable arguments. Pragmatic arguments included, for example, "The change would cost a lot of money" or "People in Czechia would not know which river is talked about." Other arguments mostly expressed disinterest: "I do not care" or "There are more important things to worry about." Both types, most commonly expressed by Czechs opposing the name change, seemed to be used as a way to delegitimize the effort by diverting attention to other issues.

In addition to analyzing basic differences between Czechs and Poles, we also tested our hypothesis that the perception of the name Olza as Polish or Czech may at least partially explain the discrepancy between name use and name preference among Czech respondents. Table 5 shows the results. As this table clearly shows, Czechs who supported the official recognition of Olza emphasized its Czech character as compared to those who opposed the recognition: they more often saw the name as Polish.

Table 5. Respondents' Support for Olza As The Official Name In Relation To The Perception Of Olza as a Czech/polish/dialectal Name By Percentage as Reported In Survey Q1 And Q2 (CZECHS Only)

\begin{tabular}{lccccr}
\hline & \multicolumn{4}{c}{ The perception of Olza as } \\
\cline { 2 - 5 } Olza as official & Czech & Polish & Dialectal & Other & Total \\
\hline Yes & 33.2 & 16.6 & 41.1 & 9.1 & 19.1 \\
No & 6.1 & 33.4 & 56.8 & 3.7 & 45.6 \\
Doesn't know & 24.3 & 23.0 & 48.4 & 4.3 & 35.3 \\
Total & 17.7 & 26.5 & 50.8 & 4,9 & 100.0 \\
\hline
\end{tabular}

Note: $\mathrm{n}=1259$, Pearson $\chi^{2}$ value $=128,655, \mathrm{df}=6, \mathrm{p}=.000$.

\section{Discussion}

Our survey has uncovered complex links between language, ideology, names, and identity. Unlike previous research on the politics of toponymy (see e.g., Yeoh 1996; Palonen 2008; Šakaja and Stanić 20II) which focused predominantly on debates over changes of official names, we studied these debates in the context of the names' actual everyday use. The most striking paradox we discovered was the sharp discrepancy between name use and name preference. While the majority of the respondents (and presumably also the population to which we generalize our findings) use the name Olza, only a third of them wanted Olza to become the official name of the river. How can this contrast be explained? We think that this paradox might be explained by the Czechs' association of Olza with the Polish minority and the presumably Polish origin of the name. Although the name is used every day, its potential elevation to an official name appears to be seen as a threat to the Czech toponymic control of the area. Two of our findings corroborate this explanation. 
First, Czechs opposing the name change argued mainly ideologically (i.e., "This is Czechia and we should only use Czech names"), implying or even explicitly stressing that Olza is not a Czech name. And second, twice as many Czechs opposing the name change saw the name as Polish as compared to Czechs supporting the change. At face value, Table 5 might perhaps suggest that the real reason is not the association of Olza with Poles but rather with the dialect which is often considered unfit for official use. However, the dialect is often perceived as Polish and as such it is also associated with the Polish minority. So, for many respondents the association of Olza with the dialect is equal to its association with Poles. But as also became apparent in the data, for many respondents the association of Olza with the dialect is not necessarily an obstacle for their support for its official recognition. We therefore lean towards the explanation that the above-mentioned contrast is due to the "Polish" perception of the name. ${ }^{2}$

This is in accord with Puzey's (2009) observation that minority names are often perceived as a threat by the majority. The intriguing aspect of our case, however, is that the objective minority origin of a name is not required for it to be perceived as a threat. The simple association of the name with the minority seems to be sufficient. This is similar to what Alderman (2000) found in his analysis of debates surrounding the renaming of streets after M. L. King in the US South. In this research, white respondents feared the new name would associate their neighborhood with the African American community and negatively impact their businesses and real estate prices.

Two more findings transcending the immediate debate on the future of Olza are noteworthy. The Poles' use of historical arguments for the official recognition of Olza attests to a strong consciousness of their historical ties to the region which are often overlooked by many Czechs who mistakenly see the Poles as recent immigrants. Olza and other minority names thus play the role of toponymic anchors, confirming the importance of names for the minority population in a multiethnic region. Here as elsewhere, names function as expressions of their intimate link to the territory and their cultural heritage (Jordan 2009).

Finally, the importance of the phonological and aesthetic quality of a name for both Czech and Polish respondents underlines the more fundamental, existential, and emotional dimension of names. It suggests that names form a part of our intuitive understanding of order, beauty, truth, and goodness. Their pronunciation and transcription are integral components of their social role and emotional value. Corrupting the pronunciation of a name can be perceived as calling into doubt the social relations and cultural heritage which produced it (Basso I996; Kearns and Berg 2002).

\section{Conclusion}

As we have tried to show here, the symbolic power of names is not necessarily rooted in their use. Strong emotions and political leanings may be 
associated with names which are never or rarely used, yet they stand as symbols for national identity, territorial integrity, and group rights. And vice versa: names in everyday use may not necessarily be preferred as official names and attempts at changing these may be met with fierce resistance. The implication of these findings for activists and planners are clear, but they also present a challenge for us as scientists in our attempt to explain or even predict human behavior.

Names, indeed, are neither banal nor innocent. Despite this fact, only some names usually become politicized while the vast majority of others pass largely unnoticed. This fact is often overlooked in studies on the politics of toponymy many of which tend to treat the entire toponymic landscape as a permanent political battlefield. In spite of the great number of excellent studies on the subject, we believe that there still is much room for further research, especially for the inductive, anthropological kind (see Rose-Redwood, Alderman, and Azaryahu 20IO). Such research will help us to better understand the driving forces for differential politicization of names and the extent and nature of the discrepancies between official toponymies and everyday toponymic practices.

\section{Notes}

I. Transcribed into the International Phonetic Alphabet, the names are pronounced in this way: Olše - olfe, Olza - olza, Łolza wolza. We use the Czech and dialectal orthography throughout the text because it is part of the political debate. The pronunciation differences also inform this debate and influence the perception of the names by the public.

2. The Těšín region is called Zaolzie by the Poles. Zaolzie means "beyond Olza", as seen from Poland. As explained in the article, this is geographically not entirely correct because Olza/Olše becomes a border river only in its second half.
Nevertheless, Zaolzie is a very powerful political term which is associated with historic irredentist demands of the Polish community. The term is rarely used by Czechs and it almost never appears in its Czech translation (i.e., Záolší). The linguistic association of Zaolzie with Olza is clear and it may be one of the reasons why Olza evokes Polish territorial claims and generates opposition to its official recognition. However, we did not test this hypothesis.

\section{Acknowledgements}

I am deeply grateful to Professor Dr. I. M. Nick and the anonymous reviewers for their suggestions which helped to improve this article.

\section{Disclosure Statement}

No potential conflict of interest was reported by the author(s). 


\section{Funding}

The text was written with the support for the systematic long-term development of the Institute of Ethnology of the Czech Academy of Sciences (RVO: 68378076).

\section{Bibliography}

Alderman, Derek H. 2000. "Naming Places and Commemoration in the American South." The Professional Geographer 52, no. 4: 672-684.

Azaryahu, Maoz. I996. "The Power of Commemorative Street Names." Environment and Planning D: Society and Space I4, no. 3: 3 I I-330.

Basso, Keith H. I988. "Speaking with Names: Language and Landscape among the Western Apache." Cultural Anthropology 3, no. 2: 99-130.

Basso, Keith H. I996. Wisdom Sits in Places. Landscape and Language among the Western Apache. Albuquerque: University of New Mexico Press.

Berg, Lawrence D., and Jani Vuolteenaho, eds. 2009. Critical Toponymies: The Contested Politics of Place Naming. Farnham: Ashgate Publishing Ltd.

Bucher, Stanislav, René Matlovič, Alena Lukáčová, Barbora Harizal, Kvetoslava Matlovičová, Jana Kolesárová, Lenka Čermáková, Miloslav Michalko. 2013. "The Perception of Identity through Urban Toponyms in the Regional Cities of Slovakia." Anthropological Notebooks I9, no. 3: 23-40.

Cenoz, Jasone, and Durk Gorter. 2006. "Linguistic Landscape and Minority Languages." International Journal of Multilingualism 3, no. I: 67-80.

Cohen, Saul B., and Nurit Kliot. I992. "Place-Names in Israel's Ideological Struggle over the Administered Territories." Annals of the Association of American Geographers 82, no. 4: 653-680.

Gawrecki, Dan. I993. "Olza a Olše.” Těšinsko 36, no. 2: I3-I 5.

Gill, Graeme. 2005. "Changing Symbols: The Renovation of Moscow Place Names.” Russian Review 64, no. $3: 480-503$.

González-Faraco, Juan Carlos, and Michael D. Murphy. 1997. "Street Names and Political Regimes in an Andalusian Town." Ethnology 36, no. 2: I $23-148$.

Jordan, Peter, 2009. "Place Names as Ingredients of Space-Related Identity." In Geographical Names as a Part of the Cultural Heritage, edited by Peter Jordan, Hubert Bergmann, Catherine Cheetham, and Isolde Hausner, 33-39. Wien: Institut für Geographie und Regionalforschung der Universität Wien.

Kearns, Robin A., and Lawrence D. Berg. 2002. "Proclaiming Place: Towards a Geography of Place Name Pronunciation." Social \& Cultural Geography 3, no. 3: 283-302.

Light, Duncan. 2004. "Street Names in Bucharest, I990-I997: Exploring the Modern Historical Geographies of Post-Socialist Change.” Journal of Historical Geography” 30 , no. I: I 54-I72.

Lutterer, Ivan, and Rudolf Šrámek. 2004. Zeměpisná Jména v Čechách, na Moravě a ve Slezsku. Havlíčkiv Brod: Tobiáš.

Mácha, Přemysl, Horst Lassak, and Luděk Krtička. 20I8. "City Divided: Place Names and Nationalism in the Czech-Polish Borderlands." Mitteilungen Der Österreichischen Geographischen Gesellschaft I: 303-329. doi: IO.I 553/moegg I 60s303

Palonen, Emilia. 2008. "The City-Text in Post-Communist Budapest: Street Names, Memorials, and the Politics of Commemoration." GeoJournal 73, no. 3: 219-230.

Puzey, Guy, 2009. "Opportunity or Threat? the Role of Minority Toponyms in the Linguistic Landscape." Names in Multi-Lingual, Multi-Cultural and Multi-Ethnic Contact. Proceedings of the 23 rd International Congress of Onomastic Sciences August I7-22, 2008, York University, Toronto, Canada, edited by Wolfgang Ahrens, Sheila Embleton, and André Lapierre, 82 I-827. Toronto: York University.

Rose-Redwood, Reuben S. 2008. "Sixth Avenue is Now a Memory: Regimes of Spatial Inscription and the Performative Limits of the Official City-Text." Political Geography 27, no. 8: 875-894.

Rose-Redwood, Reuben S., Derek Alderman, and Maoz Azaryahu. 20ıо. "Geographies of Toponymic Inscription: New Directions in Critical Place-Name Studies.” Progress in Human Geography 34, no. 4: 453-470. 
Šakaja, Laura, 20II. "Other(Ing), Self(Portraying), Negotiating: The Spatial Codification of Values in Zagreb's City-Text." Cultural Geographies I 8, no. 4: 495-516. and, and Jelena Stanić.

Tuan, Yi-Fu. 1991. "Language and the Making of Place: A Narrative-Descriptive Approach." Annals of the Association of American Geographers 8I, no. 4: 684-696.

Yeoh, Brenda S.A. 1996. "Street-Naming and Nation-Building: Toponymic Inscriptions of Nationhood in Singapore.” Area 28, no. 3: 298-307.

\section{Notes on Contributors}

Přemysl Mácha is a cultural anthropologist currently based at the Institute of Ethnology of the Czech Academy of Sciences in Brno, Czechia. His interests include ethnicity, landscape, toponymy, sustainability, environmental history, and cultural heritage. He has conducted research in Mexico, New Mexico, and Czechia.

Correspondence to: Přemysl Mácha, Institute of Ethnology of the Czech Academy of Sciences, Veveři 97, Brno 602 o0, Czechia. Email: macha@eu.cas.cz 